\title{
Apresentação CEART em três tempos
}

Em comemoração aos 30 anos do Centro de Artes da UDESC, o presente número da Revista Nupeart traz artigos sobre a história do CEART, passada e presente, e uma seção de homenagens ao final.

Abrindo a revista, a seção História traz um artigo de Sandra Makoviecky sobre o painel "Homenagem", de Geraldo Mazzi, que ocupa o hall de entrada do Centro de Artes. Em seguida, o primeiro Diretor Geral do CEART, o artista e professor Dimas Rosa, tem sua trajetória contada por Sandra Nunes e Sandra Ramalho a partir de dois pontos de vista, artístico e humano. Um terceiro artigo, apresenta a geração de artistas que na década de $80 \mathrm{fez} \mathrm{história} \mathrm{em}$ Florianópolis, cujos grupos e coletivos foram basicamente formados no CEART.

A professora Teresa Mateiro abre a seção Tempo Presente discorrendo sobre a metodologia da história oral, utilizada na confecção dos demais artigos da seção. Foi escolhido um professor de cada um dos cinco departamentos, Música, Artes Cênicas, Artes Visuais, Moda e Design, para fornecer seu depoimento sobre o CEART. Maria Bernardete Castelan Póvoas, Valmor Beltrame, Jandira Lorenz, Mara Rúbia e Célio Teodorico tiveram suas histórias e seus pontos de vista apresentados por Rafael Dias, Jeasir Rego, Helena Garcia Vasconcelos, Marisleusa Egg e Ana Ester Correia Madeira, alunos do PPGMUS, alguns dos quais egressos dos cursos de graduação do CEART.

Finalizando o volume, quatro homenagens a colegas que nos deixaram, alguns prematuramente. Osmar Pisani (1936-2007), Dora Bay (1948-2009) e Cristina Pessi (1961- 
2013) são lembrados em textos de Sandra Ramalho e Sandra Makoviecky, suas colegas no Departamento de Artes Visuais. José Luiz Kinceler (1961-2015), ou simplesmente Zé, faleceu enquanto preparávamos o presente número da revista. Retratado por Regina Melim, a ele dedico minha especial homenagem e admiração, pela pessoa e pela obra viva que continua.

Guilherme Sauerbronn de Barros Editor convidado 